Article

\title{
Service-Learning Projects in University Degrees Based on Sustainable Development Goals: Proposals and Results
}

\author{
Paula M. Castro ${ }^{1,+(\mathbb{C})}$, Ana Ares-Pernas ${ }^{2,+}$ and Adriana Dapena ${ }^{1, *,+(\mathbb{C})}$ \\ 1 Department of Computer Engineering \& CITIC Research Center, University of A Coruña, 16071 A Coruña, \\ Spain; paula.castro@udc.es \\ 2 Department of Physics and Earth Sciences \& Polymers Group, Research Technological Center, \\ University of A Coruña, 15403 Ferrol, Spain; ana.ares@udc.es \\ * Correspondence: adriana.dapena@udc.es \\ + These authors have equally contributed to this work.
}

Received: 28 July 2020; Accepted: 21 September 2020; Published: 25 September 2020

\begin{abstract}
We present several Service-Learning projects developed considering Sustainable Development Goals to provide the students skills for the support of a sustainable society. This project begins with collecting initial impressions from surveys and reflections to know both the students' expectations and their degree of involvement in the development of a sustainable society. Next, the students design academic projects taking into account the needs of the specific collective to which the Service-Learning activity is oriented. When this design has finished, such projects are developed with the users and the activity is evaluated. During 2019-2020, these projects were done with four entities oriented to people either with Asperger's syndrome, Down syndrome, Alzheimer's disease or mental health illnesses. A total of 35 and 10 students, respectively, from the Bachelor's Degree of Engineering in Industrial Design and Product Development and from the Master's Degree in Professorship of High School have participated in this experience. We analyze the results from the perspective of the different agents involved, considering both qualitative and quantitative metrics. The results show that both users and staff are satisfied with this collaboration between the university and their entities. Moreover, this experience clearly has contributed to a better personal and professional student's development.
\end{abstract}

Keywords: disadvantaged people; higher education students; professional and curricular skills; service-learning; sustainable development goals

\section{Introduction}

The university degrees in science and engineering are usually focused on teaching contents directly related with specific competences. However, the development of a full curriculum requires other competences related with social, economic, or environmental contexts [1]. In fact, the universities must be an example for communities and society to minimize global warming emissions and to be eco-friendly [2-5]. In addition, the students will be the decision makers of our society in the future, so it is obvious that the higher educational institutions must guarantee that their graduates have the knowledge and the skills needed to develop their jobs facing the problems of the environment and introduce them in the Sustainable Development Goals (SDGs) adopted by United Nations Member States in $2015[6,7]$.

Service-Learning (SL) is a methodology in which the students achieve academic and transversal competences related to a subject while carrying out a service for community benefit [7-13]. Furthermore, SL is an educational proposal that allows to train in skills and values, promoting an inclusive, active, participatory, and committed education, through a practical experience in a real 
environment with specific needs, which promotes relationships with community and contributes to the education for citizenship [14-17]. This methodology can be used as a tool to incorporate contents in the lecture sessions as a way to teach the students about sustainability [18] or to start collaborations about sustainability issues between community partners, local governments and associations [19].

The main goal of our work is to show that the SL projects developed with undergraduate students in collaboration with surrounding entities focused on helping disavantaged people are a powerful tool to improve both the education of future professionals and the ethical values of society.

The SL methodology has been used in engineering studies in the last years, mainly for the development of foreign communities. Winkelman et al. [20] describe a project hosted by an agro-ecology center in a rural community in Mexico in which the students have enhanced leadership, ethical community engagement, or participatory planning, thus working in a real environment. Another example is found in the project presented by Seavy et al. [21], which has been developed by a group of engineering students in Cameron and India. In addition, some SL projects are focused on underprivileged communities as described in the Surbeck's project [1] that combines educational and service activities on drinking water-treatment infrastructure for those communities working the three pillars of sustainability i.e., environmental, social, and economic perspectives.

Recently, several authors have presented different projects developed in collaboration with university students and oriented to disadvantaged people. Cabedo et al. [22] have investigated how the projects involving people with serious mobility limitations can affect the acquisition of university social responsibility competences. Ruiz-Montero et al. [13] have developed a project of intergenerational SL by providing to disadvantaged older adults an opportunity to engage with younger students. Therefore, the SL methodologies seem an adequate tool to work on sustainability and develop collaborations involving community stakeholders thus introducing social justice in the students' curricula.

Although a number of advantages associated with the use of these projects have already been mentioned in previous work, this methodology also presents significant limitations from the point of view of some authors. For example, a recent work conducted by Birzer et al. [23] has analyzed different SL projects and has concluded that sometimes it could exist a risk of disempowering communities and incorrectly promote the neo-colonialism as a positive aspect to students, contrary to what the universities should pursue with these activities. An interesting study conducted by Rampasso et al. [24] has analyzed the key criteria that should be considered in the models to evaluate the insertion level of sustainability in the engineering education. As a result of this study, these authors set that criteria as the use of SL methodologies oriented to the local community for educational purposes or the use of sustainability issues in universities' installations, among others, are not directly related to the engineering curricula, being parallel activities.

Previous mentioned work show the interest of developing SL experiences in higher studies together with foreign communities [1,20,21] or surrounding entities [13,22]. Important conclusions about the acquisition of professional and transversal skills are obtained from that work. In particular, we have used the work in $[13,22]$ to establish some relevant aspects of data analysis using qualitative metrics allowing us to determine the grade of skill acquisition.

We present four SL experiences developed for two degrees of University of A Coruña (UDC): the Bachelor's Degree of Engineering in Industrial Design and Product Development and the Master's Degree in Professorship of High School. The services have been developed in collaboration with organizations serving disadvantaged collectives with special needs, like people either with Down syndrome, autism spectrum disorders, elderly with Alzheimer's disease, or people with mental illnesses (mainly schizophrenia). We have considered that the fact of working with nearby entities, instead of foreign communities as was done in the work presented above [20,21], has important advantages not only in terms of organization but also as contribution to a better surrounding community. On the other hand, the fact of involving two university degrees and four entities provides a more global vision than that described in the excellent work presented in [13] because this will give 
the opportunity of comparing data obtained from different scenarios. Moreover, we have included several groups of people with mental illness, belonging to our surrounding community, which also is an important contribution of our work since, according to our knowledge, no work in recent literature includes these types of projects working with sustainability issues. In addition, it is an opportunity for our students to learn from those who are different and gain a deep insight about problems of social justice simultaneously working on the subjects' contents related to sustainability.

In this work, we show our experience on developing SL projects based on sustainability to train students in foundations of science and technologies while they acquire professional and personal skills, including sustainability as a part of their curricula. The authors of this work have transformed the methodology of mentored work and oral defense to SL experiences related with various themes about science and engineering through the construction of objects using different types of recycled materials. In addition, the SL projects fit into SDGs numbers 4 and 17 that are quality education and partnership for sustainable development, respectively. In this work, the development of recycling projects on communities of disadvantaged people, contributes besides to goals numbers 10 (reducing inequalities) and 12 (responsible consumption and production).

The projects have been developed considering important aspects of SL: (1) to guarantee the acquisition of specific competences defined in different subjects of degrees in University of A Coruña; (2) to adapt the service to specific needs of people with functional and cognitive diversity; (3) to make the students conscious about those community needs; (4) to eliminate communication barriers; (5) to facilitate the integration of disfavored groups, and (6) achieve an academic, civic and emotional student's engagement and, in short, educate not only in contents but also in values. The idea of including SDGs is that the students acquire knowledge, skills and motivation on these SDGs for their future working life. Therefore, we expect the students to make a lifelong commitment to the environment.

This work is organized as follows. Section 2 shows the context where SL has been developed. Section 3 presents both the material and the methods, including the needs, the project description, and the evaluation methods. Section 4 describes the main results and, finally, Section 5 encloses the discussion and main conclusions extracted from this SL activity.

\section{Context}

This section describes the subjects and the entities on which the SL projects have been developed.

\subsection{University Bachelor's Degree and Master's Degree}

University of A Coruña is a public institution whose essential purpose is the generation, management and dissemination of culture and scientific, technological and professional knowledge through the development of research and teaching. University of A Coruña is territorially structured in two campuses: one of them in A Coruña and another one in Ferrol. The Campus of Ferrol is a peripheral, medium size campus that obtained the Green Flag in 2019, so not only students, professors and administration staff but also citizens, community, and political forces are involved in issues about waste, energy, health or education. Therefore, SL projects represent an appropriate tool to engage first year students in the Green Flag objectives working sustainability and social justice issues.

The SL activities have been developed in both the Bachelor's Degree of Engineering in Industrial Design and Product Development (Campus of Ferrol) and in the Master's Degree in Professorship of High School (Campus of A Coruña). It is important to notice that there are not subjects related to attention to diversity or attention to students with special needs in these university degrees.

The Bachelor's Degree of Engineering in Industrial Design and Product Development is attached to the University School of Industrial Design belongs to the area of engineering. The degree's curriculum has a total of 240 European Credit Transfer and Accumulation System (ECTS). The SL activities have been done in the subject of Physics Fundamentals (included in the first year of the basic formation). On the other hand, the Master's Degree in Professorship of High School is a degree from 
the Faculty of Educational Studies that belongs to the area of social and legal sciences. The master's curriculum has a total of 60 ECTS. The subject of Technology for Professorship of High School falls into the technology teaching specialization. Table 1 summarizes the contents and the specific competences of these two subjects.

Table 1. Summary of contents and specific competences of the subject of Physics Fundamentals and Technology for Professorship of High School.

\begin{tabular}{|c|c|c|}
\hline Type & Curricula Contents & Specific Competence \\
\hline $\begin{array}{l}\text { Physics } \\
\text { Fundamentals. }\end{array}$ & $\begin{array}{l}\text { Kinetic Energy and Work; } \\
\text { Force and Motion; } \\
\text { Electric fields; } \\
\text { Magnetic fields; } \\
\text { Physical properties } \\
\text { of materials. }\end{array}$ & $\begin{array}{l}\text { Identify, formulate and solve } \\
\text { engineering problems. } \\
\text { Capacity for design, writing and project } \\
\text { management in all its diversities and phases. } \\
\text { To know contexts and situations where are used or } \\
\text { applied the curricular contents. }\end{array}$ \\
\hline $\begin{array}{l}\text { Technology for } \\
\text { professorship of High } \\
\text { School. }\end{array}$ & $\begin{array}{l}\text { Academic curricula of High } \\
\text { School studies; Impact of } \\
\text { technology in the Society; } \\
\text { Introduction to robotic } \\
\text { and control; } \\
\text { Introduction to technical } \\
\text { materials. }\end{array}$ & $\begin{array}{l}\text { To know the history and the recent developments } \\
\text { of the subjects and their perspectives to be able to } \\
\text { transmit their dynamic vision. } \\
\text { To know the formative and cultural value of } \\
\text { the subject. } \\
\text { To know contexts and situations where are used or } \\
\text { applied the curricular contents. }\end{array}$ \\
\hline
\end{tabular}

\subsection{Partnerships}

The diversity is a fundamental component of our SL program. By serving in a diverse learning environment, the students are more likely to reduce stereotypes and increase their cultural appreciation. They will acquire competences and values different to those of the traditional academic practices. On the other hand, we have observed that the entities are increasingly demanding SL projects, which responds to needs of their groups because of the students can be a source of new ideas, energy, and enthusiasm. The SL projects also increase the collaboration between university and its surrounding entities.

The SL projects presented in this work have been developed involving four entities, which are described as the following:

- two entities dedicated to people with functional and cognitive diversity, especially including Asperger's and Down syndromes, which are focused on covering all those services required by these groups and their families. As usual, this service arises out of the need of sharing common experiences, looking for support among family members, looking for more specialized services and the union to make more strength.

- $\quad$ one entity dedicated to people with mental health illnesses, which are focused on improving their life quality in order to achieve family, social and employment insertion. This entity works in collaboration with institutions and organizations defending rights and improving the quality of human life, allowing them to achieve social and occupational integration and to promote their autonomy.

- one entity dedicated to Alzheimer's disease, providing a set of activities for physical and mental exercises of people affected by this disease, which suffer from irreversible and progressive brain disorders that slowly destroy memory and thinking skills and, eventually, the ability to carry out the simplest tasks.

\section{Materials and Methods}

Figure 1 shows a diagram of the six phases of our SL projects. In the first phase, the professors identify the community needs and look for entities to collaborate in the SL activities. In addition, 
the professors determine the degree of knowledge that the students have about those entities, the diversity groups, the types of diversity, and even the environmental sustainability. The second phase is focused on creating work groups, visiting the entity to meet users and designing the service depending on those users needs, taking into account not only their training needs but also those of resources' adaptation. The third phase corresponds to the elaboration of the student's proposals mentored by the professors. The service is developed in the next phase by means of a workshop or activity with the entity users either in the entity location or in one of the two university campuses. The activities have been evaluated in a fifth phase considering all the agents involved in the experience. Finally, in the last phase, the results are analyzed to identify their strengths and weaknesses and thus improve the activity for the incoming academic year.

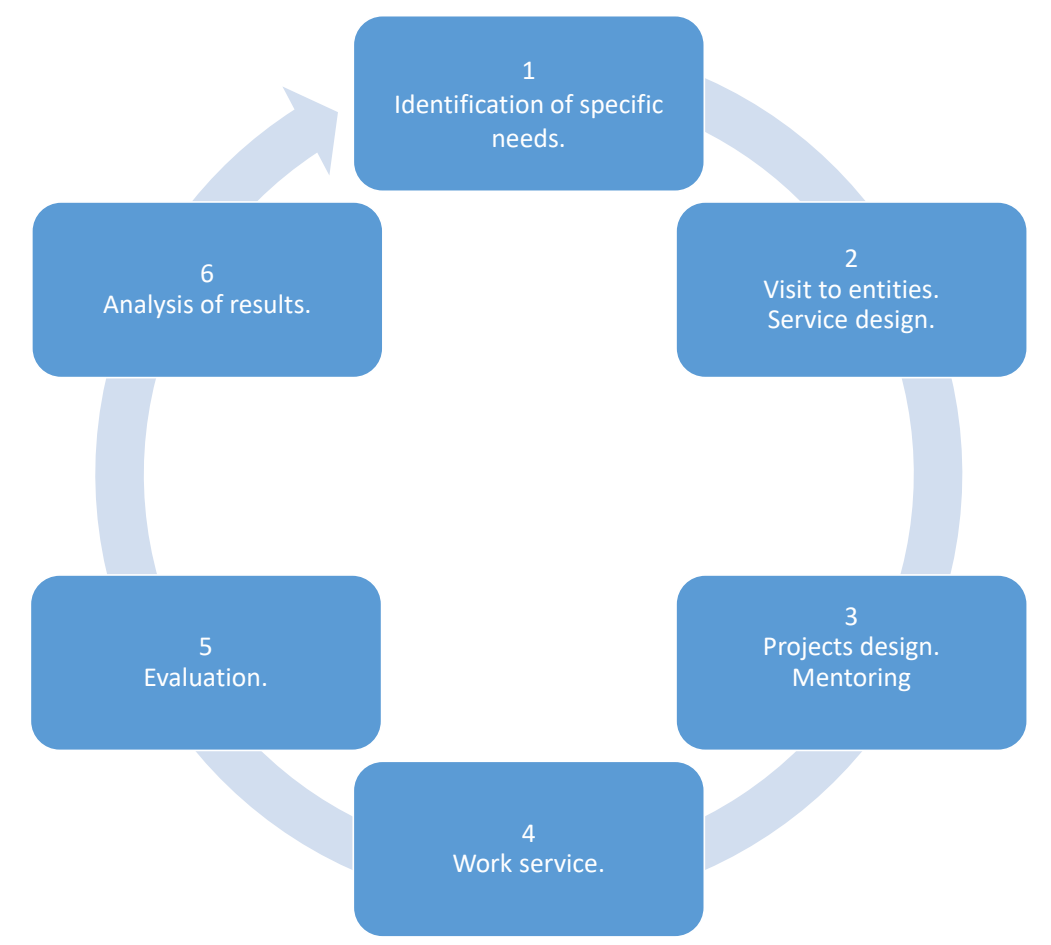

Figure 1. Main phases of the SL projects.

\subsection{Identification of Specific Needs}

The specific needs of each entity are identified by the professors and, subsequently, the students are invited to participate in the SL activities. It is important to highlight that the SL activity is not compulsory, since the students can choose between SL or traditional projects related to some subject topics. These needs are explained to the students and an initial assessment on their concerns is answered. Moreover, since the acquisition of environmental competences is one of the goals of our experience, an initial assessment survey is carried out dealing with various aspects related to sustainability. Table 2 shows some of the questions from these initial assessment surveys. 
Table 2. Initial assessment surveys. The content is a translation of the original surveys in Spanish.

\begin{tabular}{ll}
\hline Survey of Previous Concerns & Environmental Survey \\
\hline $\begin{array}{ll}{[P C S 1] \text { Would you rather do SL or a traditional }} \\
\text { project in this subject? Response: Yes; No }\end{array}$ & $\begin{array}{l}{[E S 1] \text { Have you heard about UDC Healthy Office? }} \\
\text { Response: Yes but I don't know of any action; Yes; } \\
\text { No }\end{array}$ \\
\hline $\begin{array}{l}{[P C S 2] \text { Have you done SL in other subjects? }} \\
\text { Response: Yes; No }\end{array}$ & $\begin{array}{l}{[E S 2] \text { Have you heard about UDC Cooperation }} \\
\text { and Volunteer Office? Response: Yes but I don't } \\
\text { know of any action; Yes; No }\end{array}$ \\
\hline $\begin{array}{l}{[P C S 3] \text { What are your expectations? }} \\
{[P C S 4] \text { What are your concerns? }}\end{array}$ & $\begin{array}{l}\text { Response: Yes but I don't know of any action; Yes; } \\
\text { No }\end{array}$ \\
\hline$[P C S 5]$ What motivates you to participate in SL? & $\begin{array}{l}{[E S 4] \text { Do you know the Sustainability }} \\
\text { Development Goals? Response: Yes; No }\end{array}$ \\
\hline
\end{tabular}

\subsection{Visit to Entities and Service Design}

For service design, it is necessary to analyze several aspects: (1) to evaluate the best place to develop the service (in general, entity or university); (2) to determine if the final users will work in groups or individually; (3) to define ways to establish a correct interaction between the students and the users (for example, use of oral and/or written communication, use of pictograms, etc.), and (4) to determine the number of sessions and their duration.

Since we have a large number of students involved in the development of these projects, they are divided into different work groups. Each group is responsible for organizing the assigned activity. The professors visit the entities and, if the conditions make it possible, also the students group. However, sometimes all the students cannot attend to the visit because of the difficulty to combine their schedules with those of the association. The entity staff give professors and students a short training about each disease and advices on how to approach the SL activity to be more successful. The main objective of these talks is to establish a first contact between all the agents from the university and the entities and to learn more about the functional diversity suffered by each user or users group, observing their skills and their way of working. In addition, the entity staff gives some recommendations to elaborate the support materials adapted to such features.

After the visits, all the students have enough time to prepare their corresponding activities. The professors support them at all times, although they carried out a passive role, intervening only when the students requested it with mentoring tasks.

\subsection{Project Design and Mentoring}

As it was mentioned above, the objective of these projects is to provide a service to a specific group, with special functional and cognitive capacities, simultaneously allowing the students to acquire specific and transversal competences.

For the project design, each student must do the following:

- Provide any object for its construction with recycled material.

- Obtain the necessary recycled material for the construction of the proposed object.

- Make an A4 sheet with the step-by-step description of the making of the object using that materials, and deliver it also in digital format. This sheet should include the relation of the necessary materials for such a construction. It should be as simple as possible, with clear instructions and images.

Since the subjects involved in this SL experience have different specific competences, indicated in Table 1, additional materials are elaborated for each case, as follows: 
- For the Bachelor's Degree of Engineering in Industrial Design and Product Development, the students must prepare an explanation about the material properties. For example, if the recycled plastic is a water bottle, they must explain characteristics about the polyethylene.

- For the Master's Degree of Professorship of High School, the students must also, collaboratively and working as a team, prepare slides or videos to explain the relationship between their project and the environment sustainability during the SL activity.

The objective is to develop a service adapted to specific collectives that elaborate objects using recycled material encouraging critical thinking about the environmental impact of some technological advances so this service can contribute to the Environmental Education (EE) of both the students and the end-beneficiaries. Since each project has been developed considering the user skills, we will show one example of each one of them. For further information about the projects, see also Table 4.

\subsubsection{Construction of a Car with a Windmill}

The project has been developed for a group of people suffering from the Asperger's syndrome. This activity is part of the project called "Technology and Society", which seeks to highlight the impact of technology on the life of society today. The project has been carried out with materials very easy to get at home: bottles, caps, elastic bands, toothpicks, and straws.

As an example, Figure 2 shows the sheet done by one student with the steps for the construction of the car. Its implementation is simple, although the users often need advice from the students. This project allows users to become familiar with basic technology concepts based on simple mechanisms to create movement. The fact of having to create simple gears is attractive for these types of users who usually show great interest in knowing how the mechanisms work.

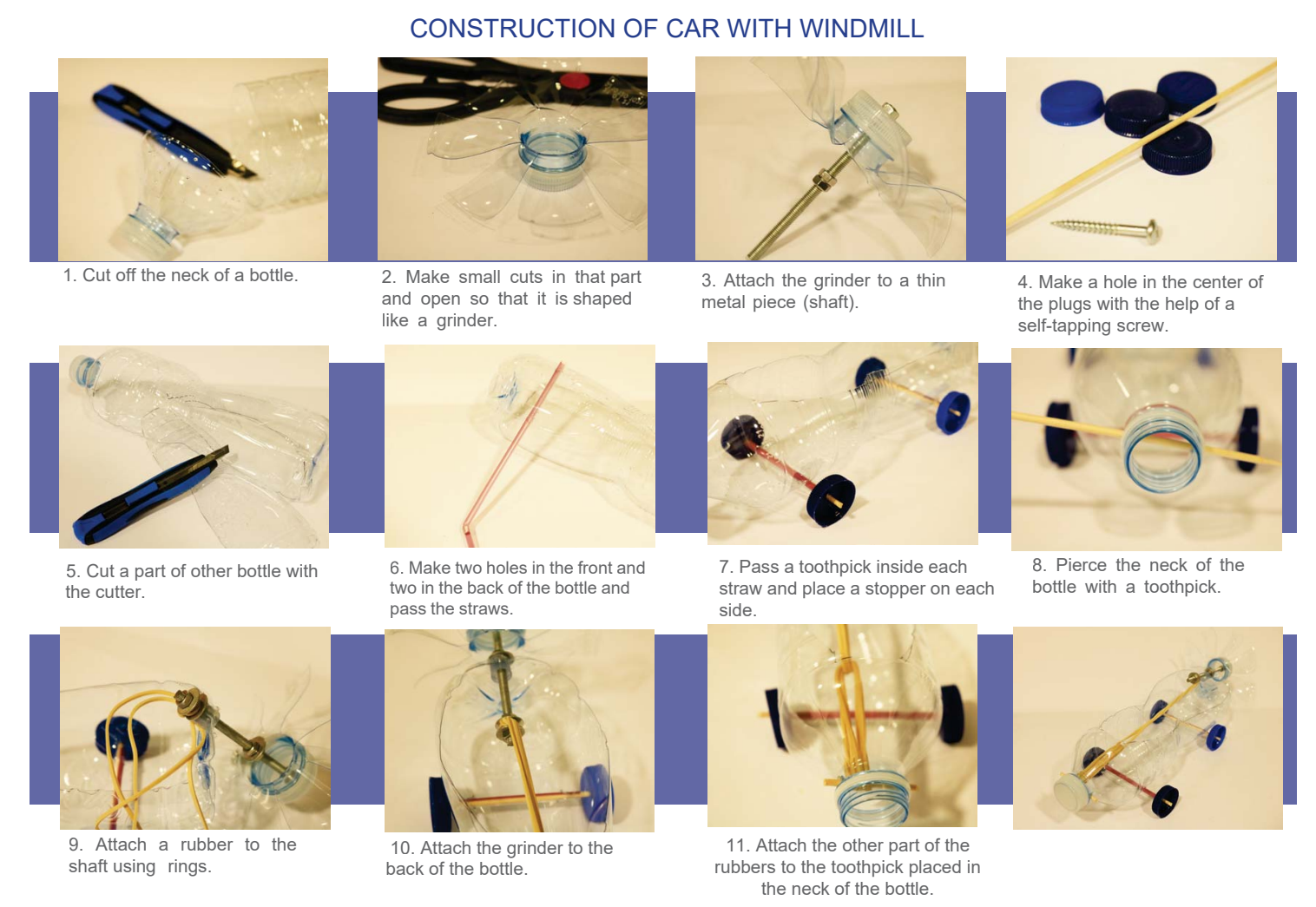

Figure 2. Construction of a "car with windmill". The content is a translation of the original material in Spanish.

With regard to recycle, reuse, and reduce, the utilization of plastic bottles and caps as basic material also allows for introducing the differences existing between them. The students must search 
information (origin, properties, recycling possibilities) about these materials, that is, PE for caps and PET for bottles. With this project, the students can learn more about reusing plastic materials, but also can introduce users about recycling, reusing, and reducing ideas.

\subsubsection{Box Design from Different Types of Commodity Plastics}

This SL activity has been developed with an entity dedicated to people with Down syndrome. The activity is part of a great entity project called "Put yourself in my shoes" to raise awareness on the general population about the problems that this group must face in their day to day. To carry out this project, each person with Down syndrome has designed their own shoe box with recycled materials supported by the help of the students. Different recycled materials have been used to design the boxes: CDs, straws, bottle caps, soda, and water bottles, cables and so on. Each design has been personalized depending on each user. The students have also designed leaflets explaining the plastic composition of the recycled object (see Figure 3). In addition, some materials with pictograms and simple explanations have been elaborated for those users that could not read (see Figure 4).

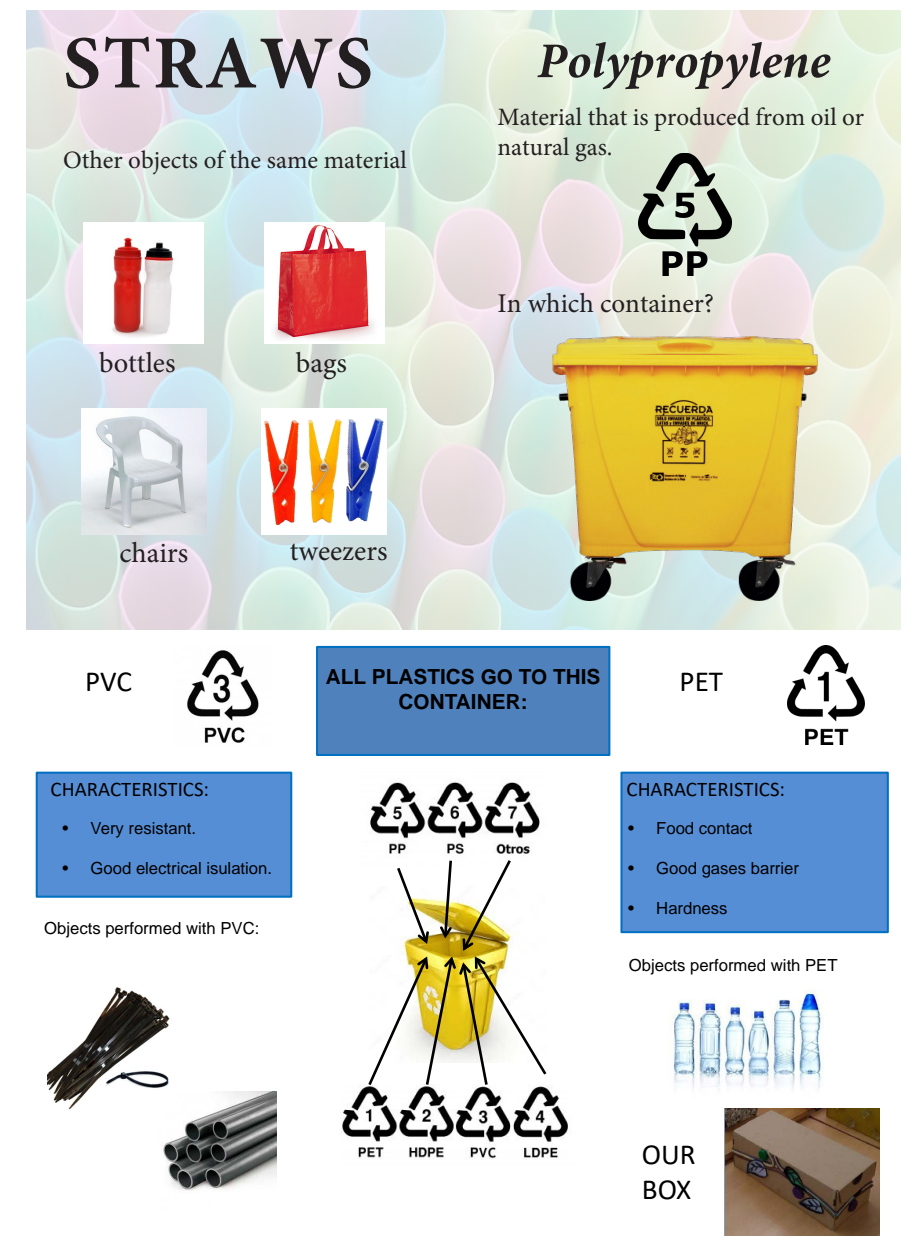

Figure 3. Explanation of types of plastics used to build boxes and recycling. The content is a translation of the original material in Spanish. 


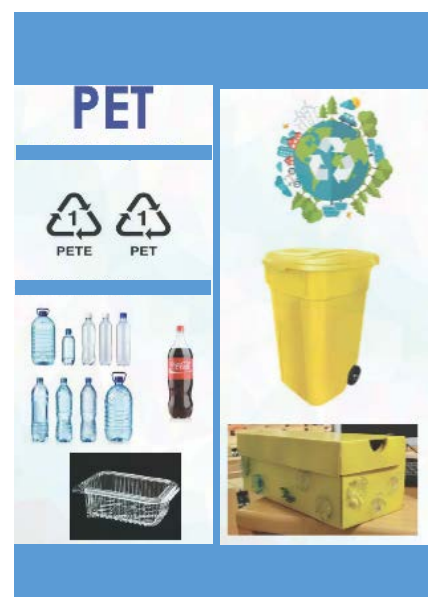

Figure 4. Explanation of types of plastics used to build boxes and recycling for users who cannot read.

The activity has allowed, on the one hand, to promote the separation, reusing and recycling tasks on these users. In addition, the students and the users learn that there are different types of plastics with also different properties. This activity allows for fostering social relationships between people with Down syndrome and outsiders, which is strongly demanded, especially by young users. On the other hand, as the boxes have been designed within the framework of a project aimed at the general population, it is expected that the "Put yourself in my shoes" campaign will serve not only to raise awareness about the Down syndrome but about the relevance of separating waste at home or about the possibility of giving waste a second life by doing reusing activities.

\subsubsection{Designing Jewelery and Learning Physics with Recycled Materials}

The SL project was carried out for people with mental illnesses, mainly schizophrenia. The objective of this project is, first of all, to promote social relationships between users and outsiders. On the other hand, since most people with mental illness acquired the disease at an adult age after finished their studies, such a scientific fair motivates them more than other tasks usually carried out at the entity location (wooden workshops, leather, laundry, kitchen, or gardening). In addition, jewelery making provides an extra income for the center's finances.

The projects are focused on explaining Physics fundamentals (forces, pressure, density, optical, and so on) and plastic recycling (plastic identification, waste separation or reusing). Figure 5 shows two examples: the first one about plastic waste (water or soda bottles, shampoo or milk bottles, and so on), which are used to design earrings or pendants to be sold in a solidarity market to get money for the entity, while the second example is a lamp made with plastic bags, which is used to explain recycling and basic electricity contents.

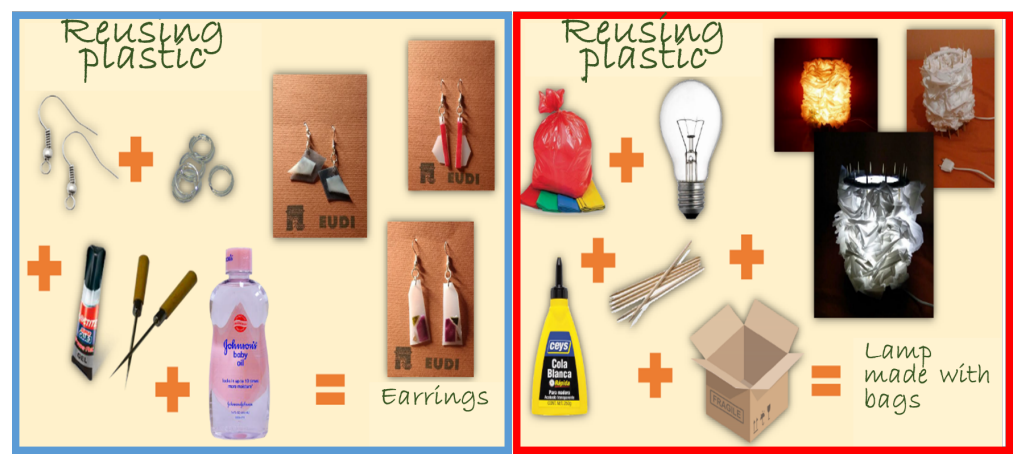

Figure 5. Designing jewelery and learning physics from recycled materials. The content is a translation of the original original material in Spanish. 


\subsubsection{Construction of Pots to Grow Vegetables}

The project has been developed for a collective with Alzheimer's disease. The activity has been performed throughout three sessions. In the first one, the students have explained to the users the problems of using plastic nowadays and the benefits of reducing, reusing and recycling. The use of games like riddles or bingo, also designed by the students, favors the active participation of the users. The idea is to compare the current situation to that of past times that they could remember, thus promoting their short-term memory use. In the following two sessions, the users have manufactured a pot using recycled materials like bottles, caps, and coffee spoons that are commonly discarded at home or work (see Figure 6). This issue will help to raise awareness about separating waste in families. This second activity allows users to learn about the possibility of giving a second life to waste materials. Moreover, this helps to promote their psycho motor skills using their hands (cutting out, painting, and then building the object) and, finally, to connect their current life to the past by means of filling the pots with soil and planting vegetables in them, as for sure they did when they were young. The pig shape of some bottles also has reminded them about the period in their lives when they were raising animals at home.

Pots to grow vegetables

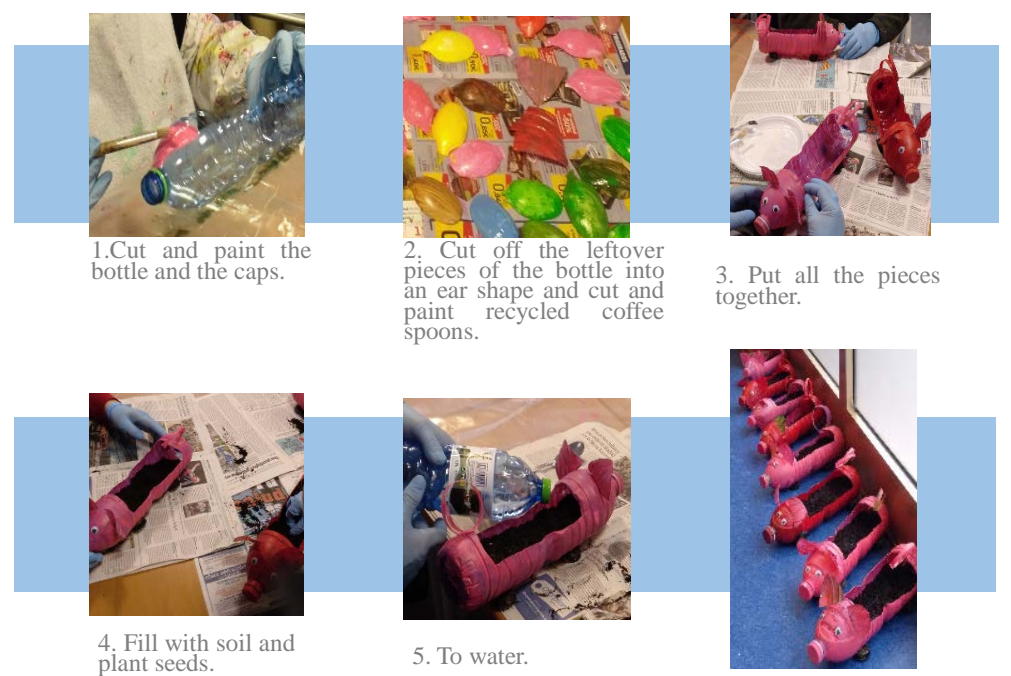

Figure 6. Construction of pots for plant growth. The content is a translation of the original material in Spanish.

\subsection{Work Service}

The service is performed following the guidelines established in the design of the SL activities (see Section 3.2). The students must mentor their projects trying to empathize with the users, while the professors and the entity staff have to be alert to situations that may alter the proper course of the activity.

On the other hand, we also consider it important that the students know services of University of A Coruña related to SL projects and sustainability. Towards this aim, during the development of our SL projects, the professors have encouraged the students to participate in some actions. In the case of $\mathrm{OCV}$, this entity supports the relationship between university and entities, so they actively participate in the project. The UDC Healthy Office promotes actions related to healthy living, some of them in the framework of "Healthy October". The Industrial Design School and their students collaborate in the "Healthy October" with one initiative called "Fruit Point" where the students could pick up or leave fruit from their home gardens. 


\subsection{Evaluation}

The SL projects, as any other teaching activity, must be qualitatively and quantitatively analyzed, including all the participants, in order to identify possible improvements and to know results and performances achieved with this activity. However, it is clear that, when the SL methodology is applied, it is an educational challenge to find reliable quality indicators for its assessment $[25,26]$.

For this purpose, we have elaborated several surveys trying to collect assessments of the experience participants. Therefore, both the students and the beneficiaries of the entity and its own staff carried out their corresponding surveys, always designed by us. Figure 7 shows some questions of these surveys. The first question uses a simple pictogram to obtain an easy and agile answer from all the agents involved in the experience i.e., entity staff, user or service beneficiaries, and the students. The other questions have been chosen to reflect on some aspects of the activity.
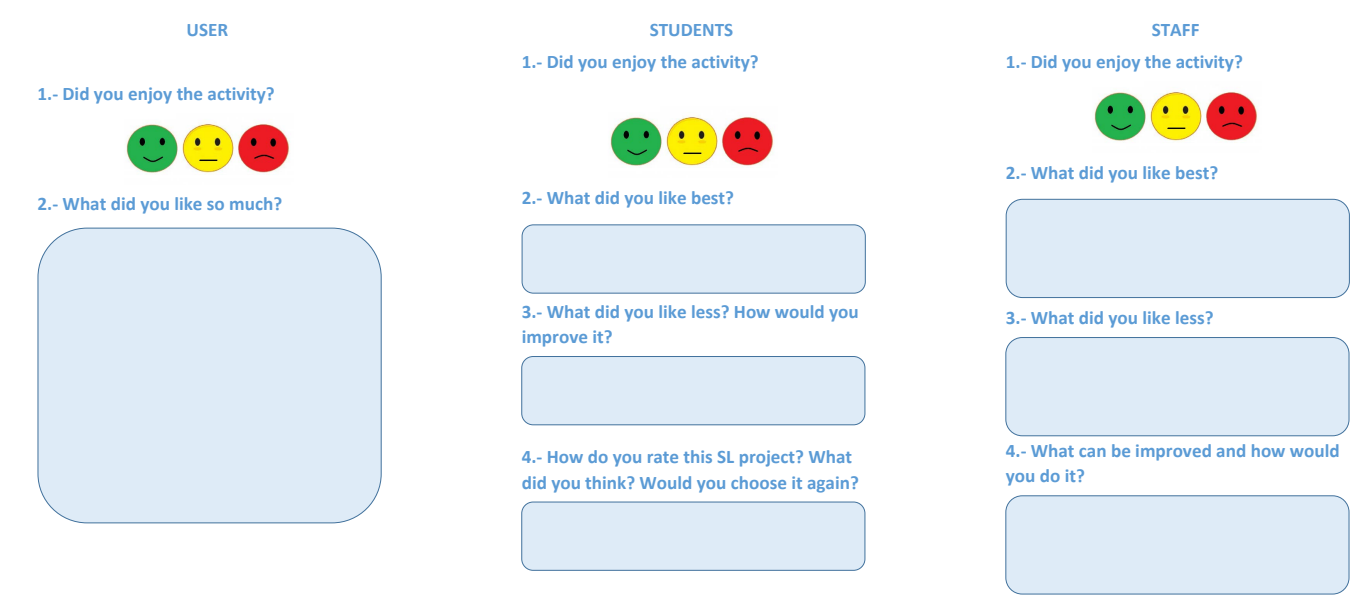

Figure 7. Surveys for the user, the students and the entity staff. The content is a translation of the original material in Spanish.

Moreover, specific surveys have been used for people who cannot read. In this case, the entity staff has assisted the students for an adequate elaboration of these surveys. For instance, Figure 8 shows one of these surveys with the support images included to help those users, so the students can help users to select that image by orally asking them some questions.
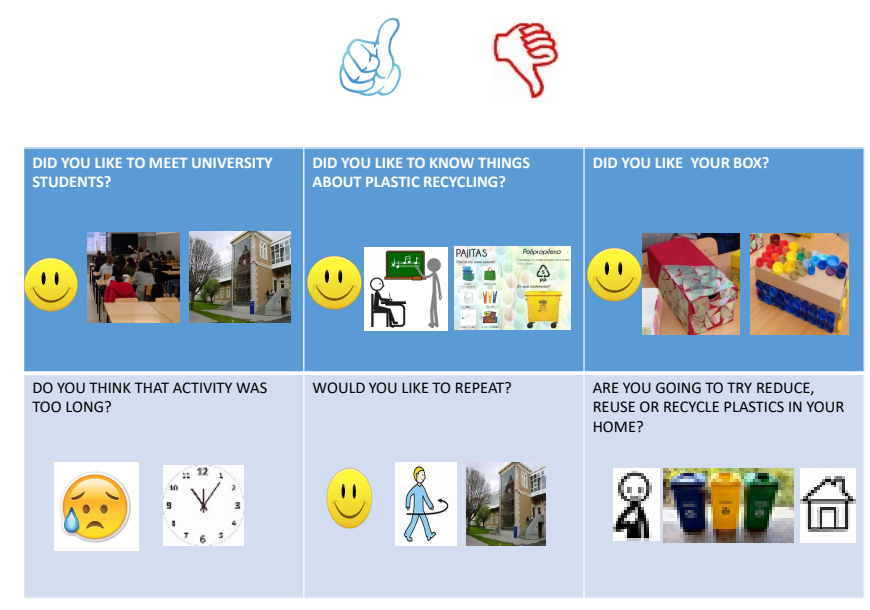

Figure 8. Survey for users who can not read. The content is a translation of the original material in Spanish. 
For the academic assessment of our students, different rubrics were defined and adapted to the objectives of each subject. These rubrics consider items to evaluate the acquisition of several transversal competences and they are published online at the beginning of the academic year to guarantee that the students know the evaluation criteria. For instance, Table 3 shows a rubric used for us to evaluate six competences.

Table 3. Rubric to evaluate the acquisition of some competences by the students involved in the SL projects. The content is a translation of the original material in Spanish.

\begin{tabular}{|c|c|c|c|c|}
\hline $\begin{array}{l}\text { Evaluated } \\
\text { Competences }\end{array}$ & $\begin{array}{l}\text { Not Fully } \\
\text { (0 points) }\end{array}$ & $\begin{array}{l}\text { Poor } \\
\text { Compliance } \\
\text { (1 point) }\end{array}$ & $\begin{array}{l}\text { Enough } \\
\text { Compliance } \\
\text { ( } 2 \text { points) }\end{array}$ & $\begin{array}{l}\text { Excellent } \\
\text { Compliance } \\
\text { ( } 3 \text { points) }\end{array}$ \\
\hline $\begin{array}{l}\text { Work effectively as an } \\
\text { individual and as a } \\
\text { member of a } \\
\text { multidisciplinary } \\
\text { group. }\end{array}$ & $\begin{array}{l}\text { The project did } \\
\text { not started. }\end{array}$ & $\begin{array}{l}\text { The project was } \\
\text { partially } \\
\text { completed. }\end{array}$ & $\begin{array}{l}\text { The student } \\
\text { developed a } \\
\text { correct work but } \\
\text { without } \\
\text { respecting } \\
\text { deadlines. }\end{array}$ & $\begin{array}{l}\text { The student } \\
\text { developed a } \\
\text { correct work } \\
\text { respecting } \\
\text { deadlines. }\end{array}$ \\
\hline $\begin{array}{l}\text { Ability to design and } \\
\text { prepare a project } \\
\text { adapted to the need of } \\
\text { the users. }\end{array}$ & $\begin{array}{l}\text { The student } \\
\text { elaborated } \\
\text { original material } \\
\text { for the project. }\end{array}$ & $\begin{array}{l}\text { The student } \\
\text { elaborated } \\
\text { original material. } \\
\text { Many errors in } \\
\text { the contents and } \\
\text { no adapted to } \\
\text { the objectives of } \\
\text { the activity or to } \\
\text { the needs of the } \\
\text { users. }\end{array}$ & $\begin{array}{l}\text { The student } \\
\text { elaborated } \\
\text { original material. } \\
\text { No errors in the } \\
\text { contents of the } \\
\text { material. It } \\
\text { could be better } \\
\text { adapted to the } \\
\text { objectives of the } \\
\text { activity and the } \\
\text { needs of the } \\
\text { users. }\end{array}$ & $\begin{array}{l}\text { No errors in } \\
\text { contents of the } \\
\text { material. Good } \\
\text { quality. It is } \\
\text { adapted to both } \\
\text { objectives of the } \\
\text { activity and user } \\
\text { needs. }\end{array}$ \\
\hline $\begin{array}{l}\text { Work collaboratively. } \\
\text { Know about group } \\
\text { dynamics and } \\
\text { teamwork. }\end{array}$ & $\begin{array}{l}\text { The student } \\
\text { does not seem } \\
\text { comfortable in } \\
\text { the group and } \\
\text { does not follow } \\
\text { the instructions. }\end{array}$ & $\begin{array}{l}\text { The student } \\
\text { does not seem } \\
\text { comfortable in } \\
\text { the group but } \\
\text { follows the } \\
\text { instructions. }\end{array}$ & $\begin{array}{l}\text { The student } \\
\text { seems } \\
\text { comfortable in } \\
\text { the group but } \\
\text { does not follow } \\
\text { the instructions. }\end{array}$ & $\begin{array}{l}\text { The student } \\
\text { seems } \\
\text { comfortable in } \\
\text { the group and } \\
\text { follows the } \\
\text { instructions. }\end{array}$ \\
\hline $\begin{array}{l}\text { Communicate } \\
\text { effectively in a } \\
\text { working environment. }\end{array}$ & $\begin{array}{l}\text { The student } \\
\text { does not } \\
\text { communicate } \\
\text { the appropriate } \\
\text { concepts and the } \\
\text { users do not } \\
\text { understand. }\end{array}$ & $\begin{array}{l}\text { The student } \\
\text { does not } \\
\text { communicate } \\
\text { the appropriate } \\
\text { concepts, but the } \\
\text { users } \\
\text { understand. }\end{array}$ & $\begin{array}{l}\text { The student } \\
\text { communicates } \\
\text { the appropriate } \\
\text { concepts and the } \\
\text { users do not } \\
\text { understand. }\end{array}$ & $\begin{array}{l}\text { The student } \\
\text { communicates } \\
\text { the appropriate } \\
\text { concepts and the } \\
\text { users } \\
\text { understand. }\end{array}$ \\
\hline $\begin{array}{l}\text { Express correctly, } \\
\text { in the official } \\
\text { languages. }\end{array}$ & $\begin{array}{l}\text { The student has } \\
\text { problems with } \\
\text { public speaking } \\
\text { and with the } \\
\text { adjustment to } \\
\text { the audience. }\end{array}$ & $\begin{array}{l}\text { The student has } \\
\text { not problems } \\
\text { with public } \\
\text { speaking. }\end{array}$ & $\begin{array}{l}\text { The student has } \\
\text { problems with } \\
\text { public speaking } \\
\text { but the } \\
\text { adjustment to } \\
\text { the audience is } \\
\text { quite good. }\end{array}$ & $\begin{array}{l}\text { The student } \\
\text { does not have } \\
\text { problems with } \\
\text { public speaking } \\
\text { or with the } \\
\text { adjustment to } \\
\text { the audience. }\end{array}$ \\
\hline $\begin{array}{l}\text { Formulate and } \\
\text { implement } \\
\text { knowledge-based } \\
\text { solutions considering } \\
\text { diversity. }\end{array}$ & $\begin{array}{l}\text { The student } \\
\text { does not show } \\
\text { interest about } \\
\text { working with } \\
\text { the entity nor } \\
\text { about the impact } \\
\text { of its work. }\end{array}$ & $\begin{array}{l}\text { The student is } \\
\text { interested about } \\
\text { working with } \\
\text { the entity but is } \\
\text { not involved } \\
\text { enough. }\end{array}$ & $\begin{array}{l}\text { The student } \\
\text { does not show } \\
\text { interest about } \\
\text { working with } \\
\text { the entity but is } \\
\text { concerned about } \\
\text { the impact of its } \\
\text { work. }\end{array}$ & $\begin{array}{l}\text { The student } \\
\text { shows interest } \\
\text { about working } \\
\text { with the entity } \\
\text { and about the } \\
\text { impact of its } \\
\text { work. }\end{array}$ \\
\hline
\end{tabular}




\subsection{Analysis of Results}

The combination of qualitative and quantitative metrics makes it possible to cross reference and collect various perspectives from the participants, which are necessary to make data more reliable. Regarding qualitative analysis, in a first phase, the student reflections have been obtained from the surveys (questions [PCS3], [PCS4,] and [PCS5] in Table 2) and from the students' diaries presented in the online space of the subject (Moodle platform). Then, the sources have been explored and the information considered as relevant has been coded according to its content, establishing categories and subcategories by means of an inductive method. Some categories have been previously established from research although most of them have emerged throughout the data analysis. To make the analysis easier, the webQDA software has been used. This software allows the researchers to carry out the process of reduction, categorization, and coding. For the reduction of the bias' risk, two or three professors have been involved in the analytic process. All the interpretations have been based on quotations. An outside person has reviewed both the research and data analysis processes in order to ensure that the findings were consistent.

The quantitative analysis of the results obtained with the initial surveys is based on questions [PCS1], [PCS2], [ES1] , [ES2], [ES3], [ES4], and [ES5] in Table 2. The satisfaction of the involved agents has been evaluated with the first question of these surveys for users, students, and entity staff (see Figures 7 and 8). Finally, the acquisition of competences has been also evaluated using the rubric in Table 3, where each student has been evaluated by two professors: the professor who leads the SL activity and an external professor.

\section{Results}

The SL projects are being developed from the 2015/2016 academic year in the subject of Physics Fundamentals and only in the 2019/2020 academic year in the subject of Technology for Professorship of High School. Table 4 summarizes the services performed in both subjects during the second quarter of 2018/2019 academic year in the subject of Physics Fundamentals and the first quarter of 2019/2020 in the subject of Technology for Professorship of High School. Table 5 presents information about the users and the students. Due the the situation of lock-down in Spain as a consequence of Covid-19, the SL experience could not be done during the second quarter of 2020.

Table 4. Summary of the SL projects developed from February 2019 to January 2020.

\begin{tabular}{|c|c|c|}
\hline Users & Students & Service Description \\
\hline $\begin{array}{l}5 \text { people with } \\
\text { Asperger } \\
\text { syndrome. }\end{array}$ & $\begin{array}{l}10 \text { students of } \\
\text { the Technology } \\
\text { for Professorship } \\
\text { of Higher School } \\
\text { subject. }\end{array}$ & $\begin{array}{l}5 \text { groups of } 2 \text { students. They design projects based on } \\
\text { constructing an everyday object, in the framework of the overall } \\
\text { project entitled "Technology and Society", using simple } \\
\text { mechanisms (see Section 3.3.1). They also create and present } \\
\text { videos about recycling and the impact of the technology in our } \\
\text { current life. The service takes place in the entity location over two } \\
\text { sessions of two hours each. }\end{array}$ \\
\hline $\begin{array}{l}60 \text { people with } \\
\text { Down syndrome. }\end{array}$ & $\begin{array}{l}11 \text { students of } \\
\text { the Physics } \\
\text { Fundamentals } \\
\text { subject. }\end{array}$ & $\begin{array}{l}4 \text { groups of } 2 \text { students and } 1 \text { group of } 3 \text { students. They design } \\
\text { boxes with recycled materials for a project called "Put yourself in } \\
\text { my shoes" (see Section 3.3.2). They also adapt multimedia } \\
\text { materials to be understood by all users. The service takes place in } \\
\text { the faculty rooms over three sessions of two hours. }\end{array}$ \\
\hline $\begin{array}{l}36 \text { people with } \\
\text { mental illnesses } \\
\text { (mainly } \\
\text { schizophrenia). }\end{array}$ & $\begin{array}{l}12 \text { students of } \\
\text { the Physics } \\
\text { Fundamentals } \\
\text { subject. }\end{array}$ & $\begin{array}{l}6 \text { groups of } 2 \text { students organize a scientific fair with three stands } \\
\text { based on Physics for daily life and three stands based on } \\
\text { recycling and reusing (see Section 3.3.3). The service takes place } \\
\text { in the entity location over one session of three hours. }\end{array}$ \\
\hline $\begin{array}{l}36 \text { elderly with } \\
\text { Alzheimer's } \\
\text { disease. }\end{array}$ & $\begin{array}{l}12 \text { students of } \\
\text { the Physics } \\
\text { Fundamentals } \\
\text { subject. }\end{array}$ & $\begin{array}{l}2 \text { groups of } 6 \text { students develop "Construction of pots to grow } \\
\text { vegetable" projects (see Section 3.3.4). The service takes place in } \\
\text { two locations of the entity over three sessions of one hour each. }\end{array}$ \\
\hline
\end{tabular}


Table 5. Information about the users and the students involved in the SL project developed from February 2019 to January 2020.

\begin{tabular}{|c|c|c|}
\hline Projects & Users & Students \\
\hline $\begin{array}{l}\text { Project for people with Asperger } \\
\text { syndrome. }\end{array}$ & 5 users, $21-40$ years old. & $\begin{array}{l}10 \text { students, } 25-35 \text { years old, } 6 \text { male, } \\
4 \text { female. }\end{array}$ \\
\hline $\begin{array}{l}\text { Project for people with Down } \\
\text { syndrome. }\end{array}$ & 60 users, $10-45$ years old. & $\begin{array}{l}11 \text { students, } 18-20 \text { years old, } 4 \text { male, } \\
7 \text { female. }\end{array}$ \\
\hline $\begin{array}{l}\text { Project for people with mental } \\
\text { illness. }\end{array}$ & 36 users, $18-50$ years old. & $\begin{array}{l}12 \text { students, } 18-21 \text { years old, } 5 \text { male, } \\
7 \text { female. }\end{array}$ \\
\hline $\begin{array}{l}\text { Project for people with Alzheimer's } \\
\text { disease. }\end{array}$ & 36 users, $60-80$ years old. & $\begin{array}{l}12 \text { students, } 18-19 \text { years old, } 5 \text { male, } \\
7 \text { female. }\end{array}$ \\
\hline
\end{tabular}

\subsection{Results of Initial Assessment Surveys}

Figure 9 shows the results obtained from the questions [PCS1] and [PCS2] for the initial concerns surveys described in Section 3.1. The graphs show the percentage of response (yes/no) for each question with respect to the total number of responses. We recall that all the students prefer to develop SL projects. About [PCS2], some students in the Technology for Professorship of Higher School subject, corresponding to the project for people with Asperger's syndrome, have indicated that they have done SL in other signatures. On the other hand, the students of the Physics Fundamentals subject had not developed SL projects in other subjects before. This information is important for the professors to organize the SL activities because it is very important that the students know the objective of the SL activities.

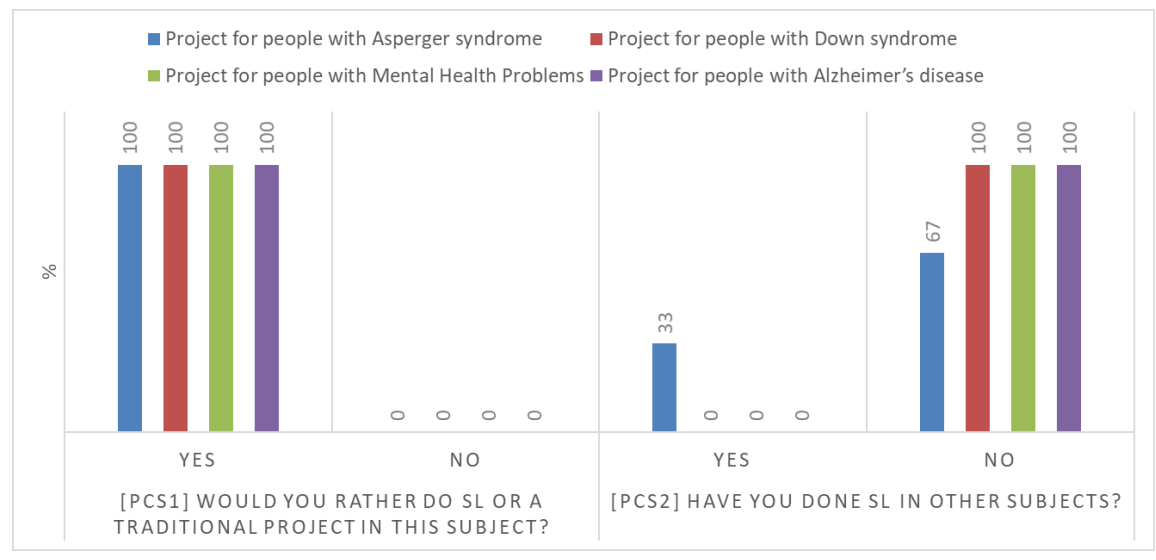

Figure 9. Results from questions $[P C S 1]$ and $[P C S 2]$ of the initial survey.

Previous student concerns and their motivation have been extracted from comments to questions [PCS3], [PCS4], and [PCS5], and analyzed using the WebQDA software for qualitative analysis. As Supplementary Materials to this paper, we provide some quoations in Spanish and the translation to English. Figure 10 shows the number of occurrences of each sentence. From the analysis of these results, three emerging categories describe the main concerns lived by the students: lack of knowing about the disability, lack of knowing about how to teach, and lack of knowing about the interaction with those users. The lack of knowing about disabilities refers to the concern that the students feel about having to interact with people who have a disease that they do not know, for example, those who had to work with people with mental illness expressed their concern about whether they would be dangerous or if they would be so medicated that they would not be able to do the activity. The following quotations are representative stereotypes:

"I am a little scared of having to expose schizophrenia patients in case they are dangerous, probably because of my misinformation about the subject" (male, 18 years old). 
"Having to work with people with Down syndrome gives me a little respect, I do not know how they will react" (female, 18 years old).

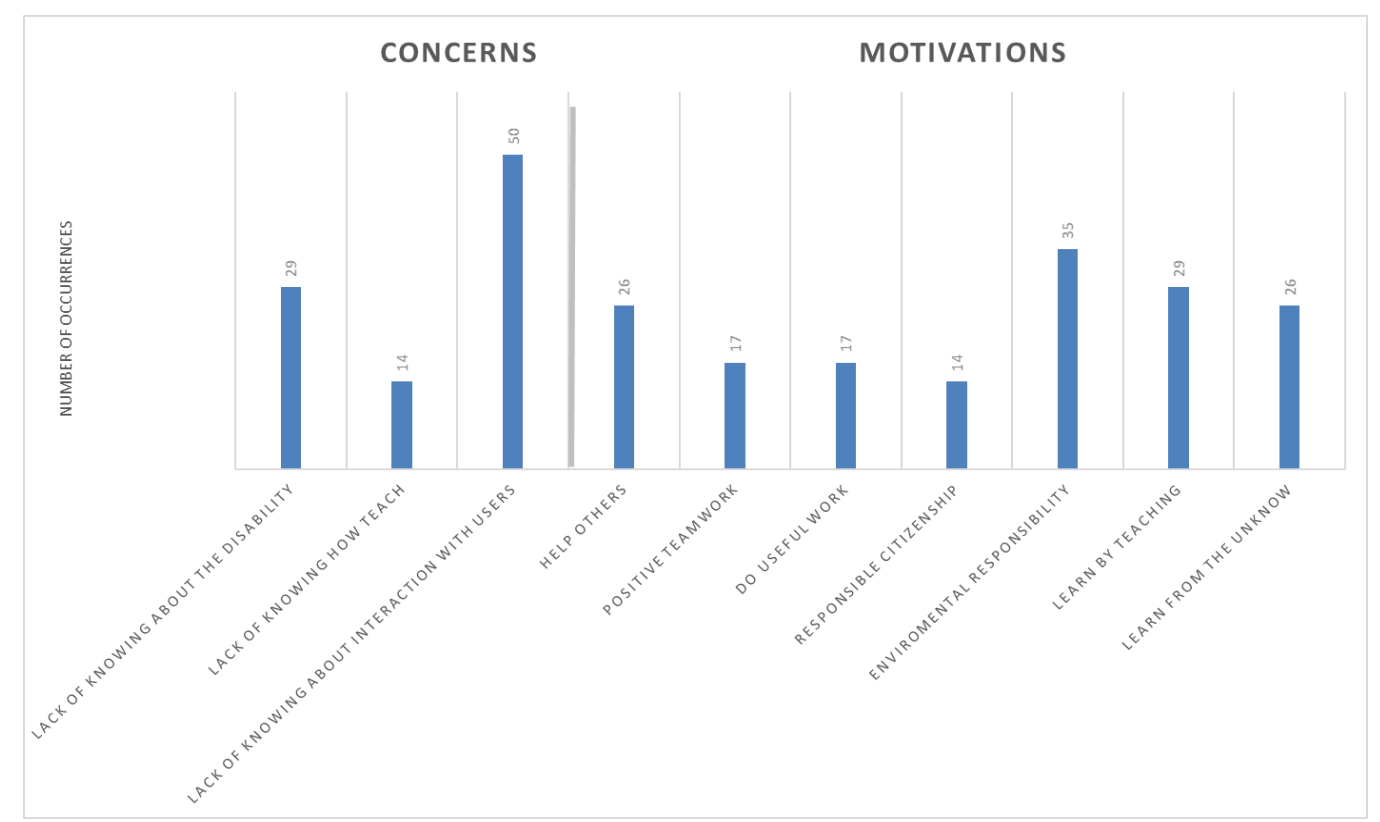

Figure 10. Results from questions $[P C S 3],[P C S 4]$ and $[P C S 5]$ analyzed using the WebQDA software for qualitative analysis.

Many students expressed their fear of not knowing how to face an audience different from their peers, not knowing how to synthesize information, not knowing how to adapt the contents, or that the public do not understand them. Some of the reflections have been the following:

"I am worried about not knowing how to transmit the information in a fun and enjoyable way, or that they get bored" (male, 19 years old).

"I am concerned that I do not know how to explain the activity well and that they may feel disappointed" (female, 18 years old).

Finally, the students have expressed their concerns about not being able to interact with the users, not attracting their attention, offending them or, in the case of users with Alzheimer's disease, about the lack of memory of the users to remember their explanations. Some comments have been the following:

"Will they have any limitations in terms of participating in the activities? Will I be able to keep their attention?" (female, 18 years old).

"I'm worried that I won't be able to understand myself with them or that they'll mistake me for a relative" (male, 18 years old).

"I don't really know how to talk to them and I don't want them to be offended by what I can say or do. I also worry about not being able to motivate them to participate" (male, 18 years old).

The students have shown more motivations than concerns when facing the SL activities, as it can be seen in Figure 10. The students valued the fact of helping other people very positively. For instance, some reflections have been the following:

"I think that our work can help to make people with this problem visible and promote their integration" (male, 21 years old).

"The activity is a good opportunity to make people who suffer from Alzheimer's disease 
have a good time. I have heard that the contact with young people can be beneficial to them" (male, 18 years old).

Some comments show that they also consider that doing teamwork is very positive in order to learn from their peers and give feedback to each other: "Working in a group is very beneficial because it allows you to exchange information with your colleagues and learn from each other" (female, 18 years old). Another motivation for the students is to do useful work not only to pass the course: "It is very interesting to do a job that is not only academic but is useful to someone" (male, 19 years old). In addition, they believe that having to learn to teach can help them to deepen the content of the subject: "We will have to go much deeper into recycling to be able to explain it clearly. We cannot give wrong information to users" (female, 18 years old).

From their comments, it can be seen that the fact of considering the development of SL projects related to sustainability raises their concern about both the environment and their responsibility as citizens. For instance, some comments have been the following:

"I had not been thinking about these sectors of the population and the needs for adaptation, integration and visibility that they have. We have to do something about this" (male, 18 years old).

"I believe that the young people can contribute to educate the population to be more sustainable" (male, 19 years old).

Finally, the students also reflected an interest in learning from those who are strangers and indicated that they believe that, during the experience, they will learn a lot from each other: "I think we will learn more than them" (female, 18 years old).

With respect to the environmental survey described in Table 2, Figure 11 shows the corresponding results. From this figure, we can conclude that the students do not have a priori knowledge either about the service in the university working on environmental issues (Green Campus, Green Flag committee), or on volunteering (OCV), or on healthy life (UDC Healthy Office) or about the main measures in terms of sustainability.

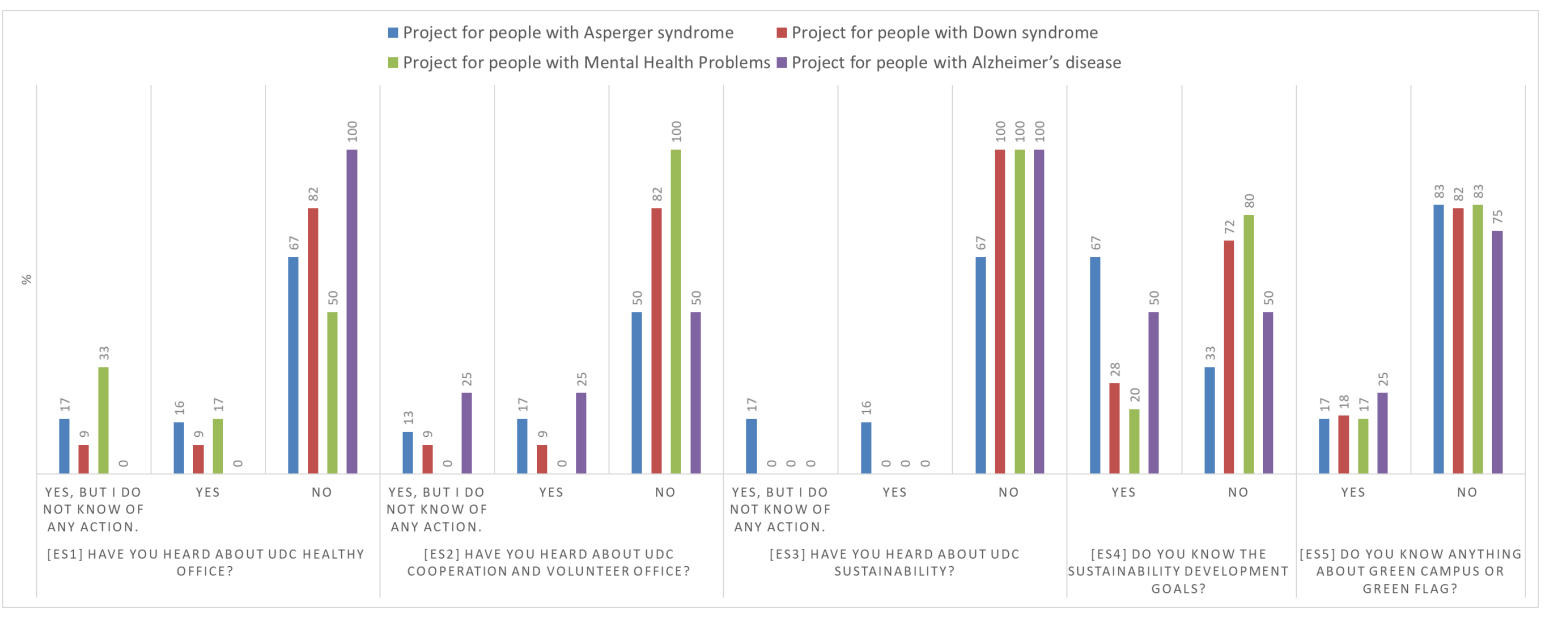

Figure 11. Results from questions from the environmental survey.

\subsection{Results from Rubrics and Surveys for the Users, the Students, and the Entity Staff}

The purpose of the SL projects is the acquisition of specific and transversal competences. In order to evaluate each student, we have used several rubrics. In Table 6, we present the results (mean and standard deviation) obtained for each topic shown in Table 3.

We can observe that the project for people with mental illness has received the lowest qualifications for many competences. A reason for these results is that this collective has involved people from 18 to 50 years old with a large rank of interests and it is not easy to design activities adapted to all of them. 
A similar behavior is observed for the competence "Ability to design and prepare a project adapted to the needs of the users" in the case of students working with people with Down syndrome. In this case, the students needed more corrections and mentoring by professors to adapt the material to the users.

Table 6. Results of using a rubric to evaluate some competences acquired by the students involved in the SL projects.

\begin{tabular}{|c|c|c|c|c|c|c|c|c|}
\hline \multirow[t]{2}{*}{ Evaluated Competence } & \multicolumn{2}{|c|}{$\begin{array}{l}\text { Project for } \\
\text { People With } \\
\text { Asperger } \\
\text { Syndrome }\end{array}$} & \multicolumn{2}{|c|}{$\begin{array}{l}\text { Project for } \\
\text { People With } \\
\text { Down } \\
\text { Syndrome }\end{array}$} & \multicolumn{2}{|c|}{$\begin{array}{l}\text { Project for } \\
\text { People With } \\
\text { Mental } \\
\text { Illness }\end{array}$} & \multicolumn{2}{|c|}{$\begin{array}{l}\text { Project for } \\
\text { People With } \\
\text { Alzehimer's } \\
\text { Disease }\end{array}$} \\
\hline & Mean & STD & Mean & STD & Mean & STD & Mean & STD \\
\hline $\begin{array}{l}\text { Work effectively as an individual } \\
\text { and as a member of a diverse and } \\
\text { multidisciplinary team, }\end{array}$ & 3 & 0 & 3 & 0 & 2.8 & 0.6 & 3 & 0 \\
\hline $\begin{array}{l}\text { Ability to design and prepare a } \\
\text { project adapted to the needs of the } \\
\text { users. }\end{array}$ & 3 & 0 & 2 & 0.1 & 2.8 & 0.6 & 3 & 0 \\
\hline $\begin{array}{l}\text { Work collaboratively. Know about } \\
\text { group dynamics and teamwork. }\end{array}$ & 3 & 0 & 3 & 0 & 2.5 & 0.8 & 3 & 0 \\
\hline $\begin{array}{l}\text { Communicate effectively in a } \\
\text { working environment. }\end{array}$ & 3 & 0 & 3 & 0 & 2.8 & 0.4 & 3 & 0 \\
\hline $\begin{array}{l}\text { Express correctly in the official } \\
\text { languages. }\end{array}$ & 3 & 0 & 3 & 0 & 2.8 & 0.4 & 3 & 0 \\
\hline $\begin{array}{l}\text { Formulate and implement } \\
\text { knowledge-based solutions } \\
\text { considering diversity. }\end{array}$ & 3 & 0 & 3 & 0 & 3 & 0 & 3 & 0 \\
\hline
\end{tabular}

As it was mentioned before in Section 3.5, different surveys have been carried out upon completion of the activity by the students, entity staff, and users. The main results identified for each activity are shown in Figure 12. As it can be seen from this figure, all the students and entity staff were completely satisfied with the activity. The users have indicated a high satisfaction, but there are some answers with a medium qualification.

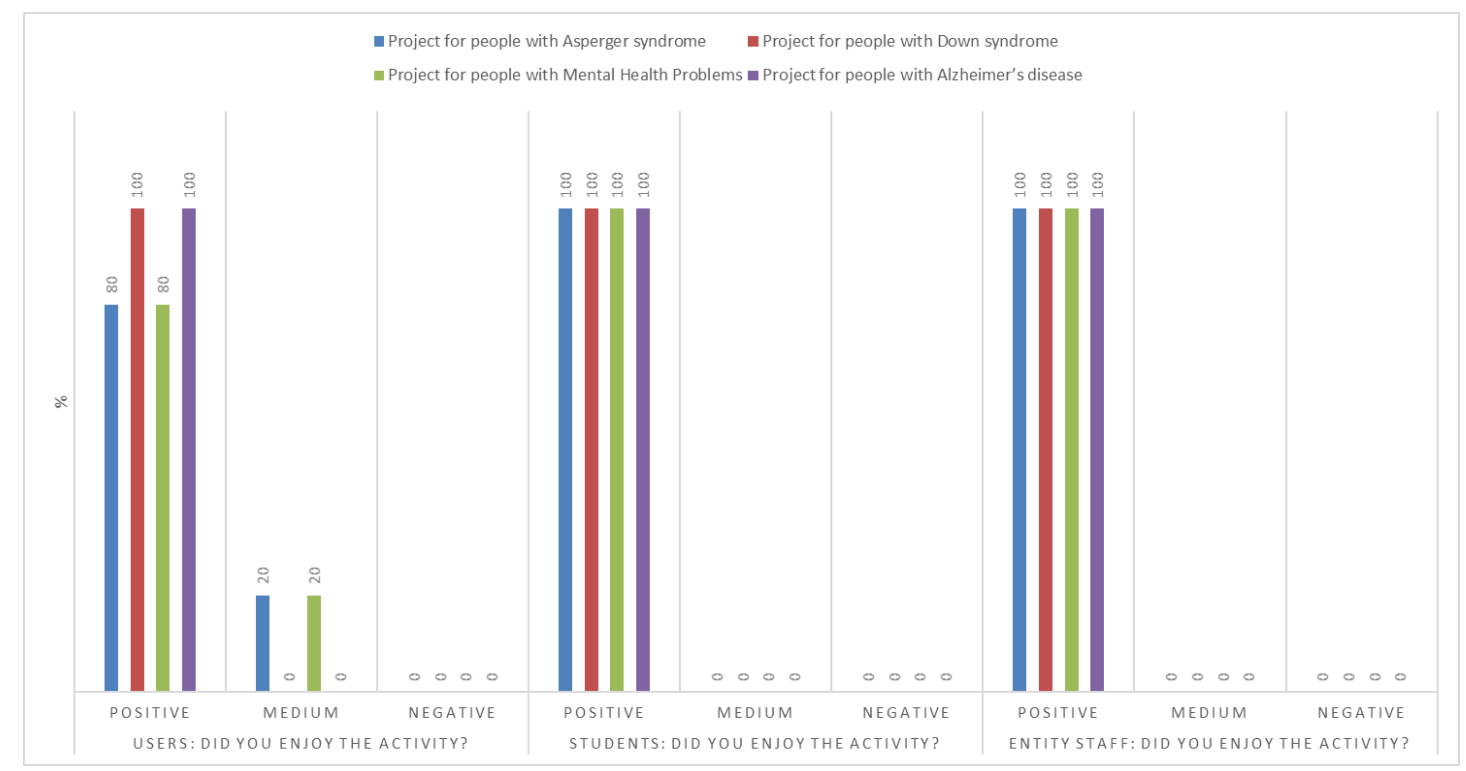

Figure 12. Results from final surveys of users, students, and entity staff.

In the qualitative analysis, different categories have emerged from the comments of the students in the final surveys and from the student's diary that have been obtained with the support of the 
WebQDA software analysis. As Supplementary Materials to this paper, we provide some original comments in Spanish and the translation to English. Figure 13 shows the categories and the number of occurrences of each one of them. These results show the most important learnings and skills achieved by the students, some of them related to environmental competences. For example, we have collected the following comments of our students:

"We were going to teach a class in Physics and recycling and we came back with a life lesson" (male, 18 years old).

"This activity has shown me that we should not be afraid to face new projects because in all of them we can learn new things" (female, 18 years old).

"I cannot understand why they are not more visible for society neither the reason for not to integrate them in it" (male, 19 years old).

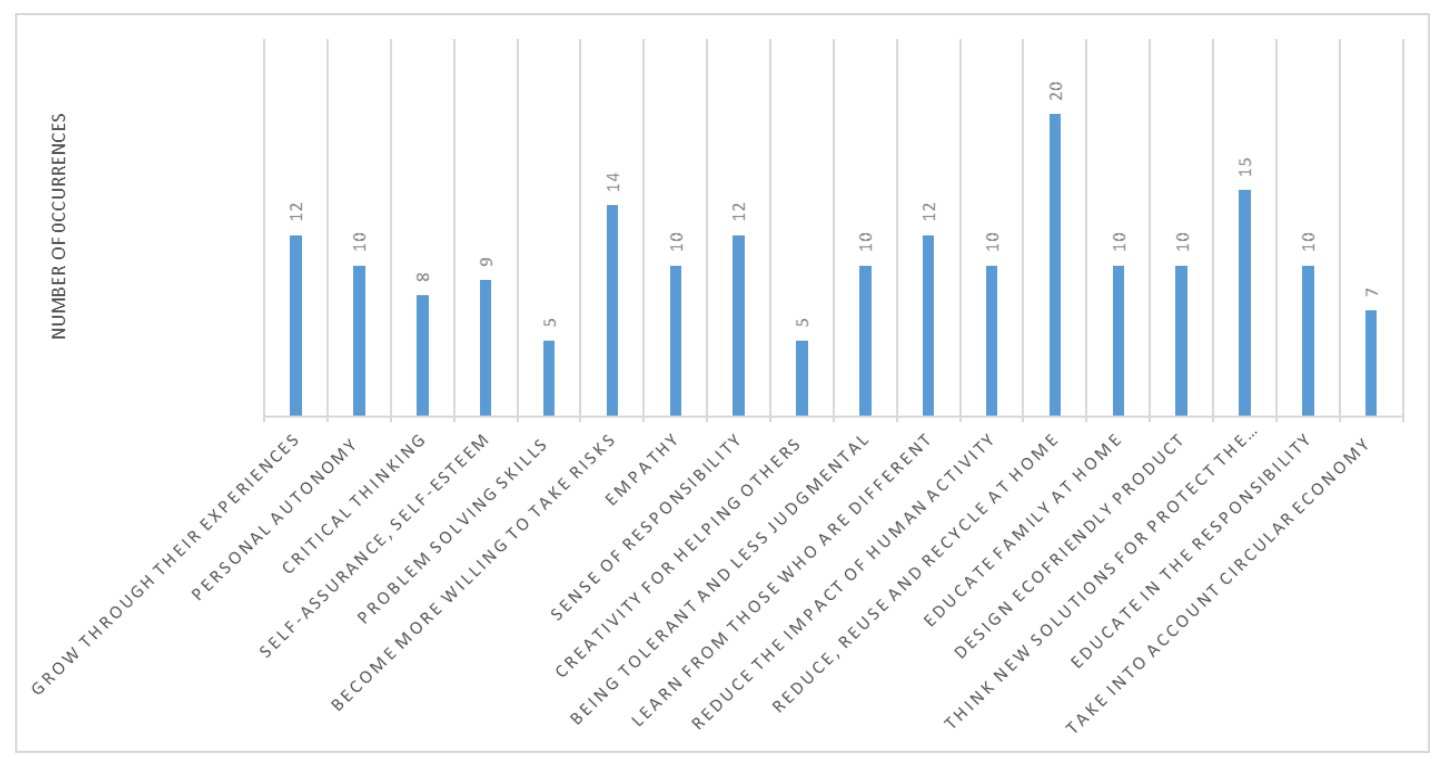

Figure 13. Results for the final surveys and the student's diary.

All of these comments show how the students have grown through this experience, achieving a more personal autonomy to deal with new projects. Moreover, the critical thinking is a skill that they have developed after the realization of these SL activities since they demonstrate to be able to face the situation in front of the society and to be critical with it.

After the completion of the SL activities, the students have more self-assurance, more self-esteem, and they are able to solve problems without having fear to start new activities. Some sentences that reflect these changes are the following:

"Although at the beginning I was worried about the result, I think we did a good job" (female, 19 years old).

"We were able to reschedule the activity on site for a group of people who had difficulties in handling the tools" (male, 18 years old).

The empathy is also a skill present in the reflections of the students: "A few hours were enough to come back down to Earth and face reality. I did not know the sad situation of these people" (female, 18 years old).

The students have developed a sense of responsibility crucial for their future jobs so they will be able to recognize the consequences of not doing it properly not only for themselves but also for the rest of those involved in the projects: "I felt a bit overwhelmed before the activity because I was afraid of doing something wrong" (male, 19 years old). 
The students have reflected in their comments the importance of being creative in order to find new solutions to adapt spaces and materials. A great part of undergraduates value positively the fact of learning from those who are different and the importance of being more tolerant and less judgemental before meeting others: "I did not expect the users to enjoy the activity so much. Their desire to learn, their response and their participation was very surprising" (female, 18 years old).

In terms of environmental skills, the students have shown after completing the SL activity their implication in reducing the impact of human activity on nature and their fundamental value as environmental educators at home. Some sentences to collect these ideas can be the following:

"Learning to teach made us have to pay more attention to the subject. I really learned a lot about recycling and environmental problems in general" (male, 18 years old).

"I learned a lot about recycling to use in my daily life and obviously when I will start to work" (female, 19 years old).

Finally, the students of the Bachelor's Degree of Engineering in Industrial Design have shown through their comments new concerns about an eco-friendly design products taking into account the model of a circular economy. They are able to recognize their relevant role as thinkers of new solutions for the protection of our planet. For instance, some students have indicated the following:

"I believe that we can contribute with many sustainable solutions for the environment in our work as designers" (male, 18 years old).

"This has made me think a lot about the products that I am going to design in all the phases; from the raw material to the waste" (female, 18 years old).

The students of the Master's Degree of Professorship of High School have indicated some important reflections about this degree:

"We need more activities or subjects related with attention of specific collectives" (female, 25 years old).

"The development of this project will help me in the future" (male, 28 years old).

Summarizing, Table 7 shows the main skills achieved by the students with the SL projects. As it was commented before, there are competences extracted from the rubric results (communication, capacity for designing projects, and work collaboratively), but the rest have been extracted from the qualitative analysis.

Table 7. Main skills achieved by the students after the SL activities.

\begin{tabular}{|c|c|c|}
\hline \multicolumn{2}{|c|}{ General Skills } & \multirow{2}{*}{$\begin{array}{l}\text { Environmental Skills } \\
\text { Reduce the impact of human } \\
\text { activity. }\end{array}$} \\
\hline Communication. & Skills for problem solving. & \\
\hline $\begin{array}{l}\text { Work in group and } \\
\text { collaboratively. }\end{array}$ & Empathy. & Educate family at home. \\
\hline Grow through their experiences. & Sense of responsibility. & $\begin{array}{l}\text { Design eco-friendly products } \\
\text { (Bachelor's degree). }\end{array}$ \\
\hline Personal autonomy. & Creativity for helping others. & $\begin{array}{l}\text { Think new solutions to protect } \\
\text { our planet (Bachelor's and } \\
\text { Master's degrees). }\end{array}$ \\
\hline Critical thinking. & $\begin{array}{l}\text { Being tolerant and less } \\
\text { prejudiced. }\end{array}$ & $\begin{array}{l}\text { Educate in the responsibility } \\
\text { (Master's degree). }\end{array}$ \\
\hline Self-assurance, self-esteem. & $\begin{array}{l}\text { Learn from those who are } \\
\text { different. }\end{array}$ & $\begin{array}{l}\text { Take into account circular } \\
\text { economy (Bachelor's and } \\
\text { Master's degrees). }\end{array}$ \\
\hline
\end{tabular}

Finally, the answers of the surveys for the users and entity staff have been analyzed by the professors to obtain valuable information about all SL projects and to improve the organization of further activities. We show some of these comments: 
"Good quality of the proposals, being practical and educational" (staff, Asperger project). "Fantastic project to visualize this collective and eliminate some stereotypes about this disability" (staff, Down syndrome project).

"The contact with unknown people was very important to stimulate their capacity of communication" (staff, mental illness project).

"Making an object to plant seeds was a very successful activity. They like everything that had to do with agriculture" (staff, Alzheimer syndrome project).

"Very fun and creative experience" (user, Asperger's syndrome project).

"The students were very nice. I want to come to the university more often" (user, Down syndrome project).

"I studied an engineering degree before my illness. I would like to be in class again" (user, mental illness project).

“When I was young we reused things, I didn't throw anything away. We have to do this again" (user, Alzheimer's disease project).

\section{Discussion and Conclusions}

The SL activities presented in this work have allowed to make an approach to the needs of community and entities who work with disadvantaged people. After these activities, all the agents involved (students, entities, and users) were very satisfied with organization, objectives, and results. These positive considerations were already described by other authors. Cabedo et al. [22] said that students considered the integration of SL activities into their university curricula positively. In addition, they explained that these activities could enable teachers to work jointly on education and social responsibility. The same conclusion is obtained by Ruiz-Montero who claimed that students show a great satisfaction and a desire to repeat the experience [13].

Students participating in our project have achieved the academic skills related with the subjects but also other practical and civic skills. From the point of view of the first ones, they have been able to work in groups performing collaborative and cooperative work, preparing a project by themselves and improving their communication skills. Moreover, these students have also achieved other social skills, like empathy, tolerance, and lack of prejudice, and general sills, like those related to problem solving or to the learning from those who are different. Cabedo et al. [22] discovered similar skills in their students involved in service learning experience with people with mobility problems and establish that this methodology could enhance awareness among students of social circumstances, such as the recognition of their privileged situation, the social responsibility behind their decision-making in the exercise of their profession, their ability to influence the lives of people through their profession, greater willingness to participate in voluntary activities, greater recognition of the work carried out by organizations such as the promoter of the project, etc. Ruiz-Montero [13] shows a project performed with older adults consisted of designing and leading physical activity and motor game session. Ruiz-Montero concludes that intergenerational SL offers too important social and educational inputs by deconstructing negative stereotypes that is increasing social skills, and providing positive experiences to both students and older adults. Due to this, service-learning can be considered a useful methodology to work these transversal skills. However, the main difference in our work is the fact that we describe sustainability SL experiences performed with engineering university students in which different groups of mentally ill people, belonging to the nearby community, were involved that it is a novelty because, according to our knowledge, no project that includes different groups of mentally disfavored people working in sustainability does not exist in the literature. As can be mentioned in the Introduction, previous studies are focused on work with foreign communities as is the case of Winkelman [20] and Seavy [21] or working with people without mental problems as Cabedo [22] and Ruiz-Montero [13]. Moreover, some authors establish that it is difficult to integrate the sustainability in the curricula; however, based on our results, SL is a useful methodology to work with social justice and sustainability with our students, working with those who are different, including the methodology in 
the curricula of students. Furthermore, it is an important opportunity to eliminate stereotypes and make the situation of these disfavored groups more visible to our students with the aim that they take it into account in their future as professionals.

In addition, we want to note that four different sustainable development goals have been involved in our SL projects: number 4 (quality education), number 10 (reduced inequalities), number 12 (responsible consumption and production), and number 17 (partnerships for the goals).

During the SL activities, the analysis of both the student's diary and the student's survey indicates that students have acquired all the skills mentioned above. From the environmental point of view, the students of Physics Fundamentals are conscious about their role as designers and engineers to choose the greenest options (eco-designs) in the creation of new products, buildings, machines, etc., and to adapt them to the different needs of disadvantaged people. On the other hand, in the subject of Technology for Professorship of High School, they are conscious about the importance of working these skills at the school from very early ages. Moreover, they learn about the importance of educating children in diversity. For example, the students claims for the need of pre-processing of some partial components in the Asperger project or, in general, more time to complete the projects. In the entity's survey, all the entities that have participated in this SL experience met their expectations and, in the user's survey, the users have provided very positive opinions about it. It is important to highlight that these users will be in charge of raising awareness of environmental problems in their families, which will allow the network of people concerned about the environment to be expanded.

As a result, the students will arrive to their professional life knowing much more about sustainability, and they will be conscious about SDGs and the importance of taking into account the diversity and the social justice for the overall society development. This represents a novelty, with respect to previous literature, and can be an example for other universities who want teach their students in sustainability and social responsibility with disadvantaged people in the nearby community.

Although a large part of our study is focused on the students, we consider it also important to reflect on the impact that these SL projects have on those users. The mere fact that the users meet university students implies an unusual approach for them, used to only deal with the entity staff and their families. In addition, they value positively being able to do projects different from those carried out by the entity staff. In addition, the importance that both the users and the entities give to carry out recycling-based projects is noteworthy.

We would like to indicate that carrying out this type of activity requires a greater effort for both academic figures i.e., students and professors, than that required by traditional practices. In addition, as limitations, we can point out the following: (1) the difficulty in combining the schedule of the subjects with that of the associations; (2) the transportation difficulties for both the students and the users; (3) the cancellation of activities due to the external facts (for example, the Covid-19 pandemic has impeded the development of the activities planned for the second quarter of the 2019-2020 academic year). We have not observed the limitation reported in [13] about the existence of users' doubts about their participation or not in these projects, although it is also something that must be taken into account in case it happens.

The authors of this work want to continue developing the activities, when the situation allows it. Our intention is to expand the integration of SL in subjects of other university degrees and to carry out a similar study including the results of more degrees, but also considering more subjects and collectives.

Supplementary Materials: The following are available online at http:/ / www.mdpi.com/2071-1050/12/19/7940/ s1, S1: Comments in Spanish and the translation to English.

Author Contributions: Conceptualization, A.A.-P. and A.D.; methodology, A.A.-P. and P.M.C.; formal analysis, P.M.C.; writing - original draft preparation, A.A.-P. and A.D.; writing—review and editing, P.M.C. All authors have read and agreed to the published version of the manuscript. 
Funding: This work has been funded by the Xunta de Galicia-FEDER (ED431C 2020/15 and ED431G2019/01 to support the Centro de Investigación de Galicia "CITIC"), the Agencia Estatal de Investigación of Spain (TEC2016-75067-C4-1-R, RED2018-102668-T, PID2019-104958RB-C42), and ERDF funds of the EU (AEI/FEDER, UE).

Acknowledgments: The authors of this article want to thank the collaboration of the entities that, through an agreement, have made the development of all these projects possible: Asperga, Saúde Mental-Ferrol-Eume-Ortegal, AFA, and TEIMA DOWN. Ana Ares-Pernas wants to thank the financial support of Vicerrectorado de Planificación Académica e Innovación Docente of University of A Coruña obtained in the I Edition of the Prizes for Teaching Innovation Projects in Service-Learning.

Conflicts of Interest: The authors declare no conflict of interest.

\section{References}

1. Surbeck, C.Q. Using a service-learning course to reinforce the three pillars of sustainability. J. Prof. Issues Eng. Educ. Pract. 2018, 144, 05017006. [CrossRef]

2. Abu Qdais, H.; Saadeh, O.; Al-Widyan, M.; Al-tal, R.; Abu-Dalo, M. Enviromental sustainability features in large university campuses: Jordan University of Science and Technology (JUST) as a model of green university. Int. J. Sustain. High. Educ. 2019, 20, 214-228. [CrossRef]

3. Adombnet, M.; Grahl, A.; Spira, F. Putting Sustainable campuses into force: Empowering students, staff and academics by the self-efficacy. Int. J. Sustain. High. Educ. 2019, 20, 470-481.

4. Choi, Y.J.; Minjung, O.; Jihye, K.; Lutzenhiser, L. Plans and living practice for the green campus of Portland state university. Sustainability 2017, 9, 252. [CrossRef]

5. Sima, M.; Grigorescu, I.; Balteanu, D. An overview of campus greening iniciatives at universities in Romania. Int. J. Sustain. High. Educ. 2019, 20, 410-422. [CrossRef]

6. Hamzah, R.Y.; Alnaser, N.W.; Alnaser, W.E. Accelerating the transformation to a green university. In Proceedings of the E3S Web of Conferences, Semarang, Indonesia, 8-10 April 2018; Volume 48, p. 06002.

7. Yuhlong, O.S.; Ku-Fan, C.; Yung-Pin, T.; Hui, I.S. How universities can work together with local communities to create a green, sustainable future. In Proceedings of the E3S Web of Conferences, Semarang, Indonesia, 8-10 April 2018; Volume 48, p. 06001.

8. Seban, D. The impact of the type of projects on preservice teacher's conceptualization for service-learning. Teach. Teach. Educ. 2013, 32, 87-97.

9. Whitley, C.T. Developing social responsibility and political engagement: Assesing the aggregate impacts of university civic engagement on associated attitudes and behaviours. Educ. Citizsh. Soc. Justice 2015, 10, 217-233. [CrossRef]

10. Hunt, J.B.; Bonham, C.; Jones, L. Understanding the goals of service learning and community-based medical education: A systematic review. Acad. Med. 2011, 86, 246-251. [CrossRef] [PubMed]

11. Conway, J.M.; Amel, E.L.; Gerwien, D.P. Teaching and learning in the social context: A meta-analysis of service learning's effects on academic, personal, social, and citizenship outcomes. Teach. Psychol. 2009, 36, 233-245. [CrossRef]

12. Castro, P.M.; Dapena, A. Teaching Science and Technology through Service Learning Experiences. In Hands-on Science: Sicence Education, Discovering and Understanding the Wonders of Nature; Filipe, M., Costa, M., Vázquez-Dorrío, J.M., Eds.; HSCI: Viana do Castelo, Portugal, 2020; pp. 183-187, ISBN 978-84-8158-841-5.

13. Ruiz-Montero, P.J.; Chiva-Bartoll, O.; Salvador-García, C.; González-García, C. Learning with Older Adults through Intergenerational Service Learning in Physical Education Teacher Education. Sustainability 2020, 12, 1127. [CrossRef]

14. Hebert, A.; Hauf, P. Student learning through service learning: Effects on academic development, civic responsibility, interpersonal skills and practical skills. Act. Learn. High. Educ. 2015, 16, 37-49. [CrossRef]

15. Kahne, J.; Westheimer, J.; Rogers, B. Service learning and citizenship in higher education. Mich. J. Community Serv. Learn. 2000, 42-51, 3239521.spec.106.

16. Melaugh, C.T.; Kindschuh, T. Engaged in waste: Two case studies from Protland state linking operational sustainability and studente-community engagement. Nurs. Forums 2017, 52, 196-206. 
17. Benning, J.L.; Surovek, A.E.; Shearer, C.R. Engagement in practice: A case study on improving community sustainability through service-learning. In Proceedings of the 2018 ASEE Annual Conference, Salt Lake City, UT, USA, 24-27 June 2018; Volume 11, pp. 331-349.

18. Coleman, K.; Murdoch, J.; Rayback, S.; Seidl, A.; Wallim K. Student's understanding of sustainability and climate change across linked service-learning courses. J. Geosci. Educ. 2017, 65, 158-167. [CrossRef]

19. Koldewyn, J.; Brain, R.G.H. Assesing community need and interest to address city-wide sustainability issues; a tri-part collaboration between local city goverment, community partners and a university. Sustainability 2016, 9, 137-143. [CrossRef]

20. Winkelman, P.M.; Penner, J.; Beittoei, A. Sustainable development for engineers through a thematic restructuring of experiential learning. In New Developments in Engineering Education for Sustainable Development; Leal Filho, W., Nesbit, S., Eds.; World Sustainable Series; Springer: Cham, Switzerland, 2016; pp. 309-321.

21. Seay, J.R; Higgins, J.C.; Joshi, C.A.; Willett, S.F. Establishing sucessful partnerships for global service learning in engineering. In Proceedings of the 5th Annual ASEE International Forum, New Orleans, LA, USA, 25 June 2016; Code 122760.

22. Cabedo, L.; Royo, M.; Moliner, L.; Guraya, T. University Social Responsibility towards engineering undergraduates: The effect of methodology on a service-learning experience. Sustainability 2018, 10, 1823. [CrossRef]

23. Birzer, C.H.; Hamilton, J. Humanitarian engineering education fieldwork and the risk of doing more harm that good. Australas. J. Eng. Educ., 2019, 24, 51-60. [CrossRef]

24. Rampasso, S.I.; Quelhas, O.L.G.; Anholon, R.; Pereira, M.B.; Miranda, J.D.A.; Alvarenga, W.S. Engineering Education for Sustainable Development: Evaluation Criteria for Brazilian Context. Sustainability 2020, 12, 3947. [CrossRef]

25. Bringle, R.G.; Phillips M.A.; Hudson, M. (Eds.) The Measure of Service Learning; Psychological Association: Washington, DC, USA, 2004.

26. Steinke, P.; Fitch, P. Assessing service-learning. Res. Pract. Assess. 2007, 2, $24-29$.

(C) 2020 by the authors. Licensee MDPI, Basel, Switzerland. This article is an open access article distributed under the terms and conditions of the Creative Commons Attribution (CC BY) license (http:/ / creativecommons.org/licenses/by/4.0/). 